\title{
Viticulture Tradition in Turkey
}

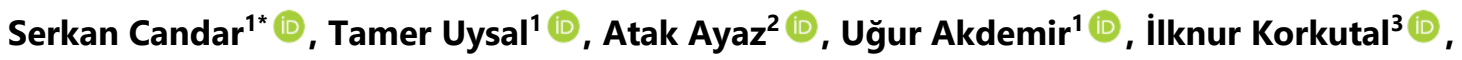 \\ Elman Bahar ${ }^{3}$ (D) \\ ${ }^{1}$ Viticulture Research Institute, Tekirdağ, Turkey. \\ ${ }^{2}$ The Graduate Institute of International and Development Studies, Department of Anthropology and Sociology, \\ Genèva, Switzerland \\ ${ }^{3}$ Department of Horticulture, Faculty of Agriculture, Tekirdağ Namik Kemal University, Tekirdağ, Turkey
}

How to cite: Candar, S., Uysal, T., Ayaz, A., Akdemir, U., Korkutal, I.., \& Bahar, E. (2021). Viticulture tradition in Turkey. Viticulture Studies (VIS), 1(1): 39 - 54. https://doi.org/10.52001/vis.2021.5

\section{Article History: \\ Received: 03.05.2021 \\ Accepted: 30.07 .2021 \\ First online: 31.07.2021}

\section{Corresponding Author}

serkan.candar@tarimorman.gov.tr

\section{Keywords}

Vitis

Distribution

History

Grape uses

Turkish viticulture

\section{Abstract}

No other plant has played as decisive a role in people's agricultural and socio-cultural activities throughout history as the grapevine. In addition to the effects of the vine plant on civilizations in history, today the economic value produced from grape and grape products distinguishes it financially from other plant species. Anatolia is a central point in the journey of Vitis species. The South Caucasus (GeorgiaAzerbaijan-Armenia) and the Fertile Crescent regions are accepted as the vine's homeland. Thus, these areas played a significant role in the cultivation and distribution of grapes. Genetic diversity also led to the diversification of usage purposes and has been an essential resource for breeding studies. In this review, the distribution of Vitis species in Anatolia has been reviewed within the scope of the current literature from different disciplines. Moreover, important $V$. vinifera $L$. varieties and their usage purposes are examined.

\section{Introduction}

Grapevine (Vitis vinifera L.) is one of the most important plants in the history of agricultural production. Besides its botanical, historical, social and cultural importance, the cultivated grapevine is one of the most widely grown fruit plants in the world (Unwin, 1991; Vivier and Pretorius, 2002; De Mattia et al., 2008).

Vine (Vitis spp.) cultivation and grape products have a culture that is as old as human history and can be found in mythologies and religious texts. In this sense, vineyard cultivation is not only an economic endeavor for Anatolian lands but also a factor ensuring cultural continuity.

Grapevine is the most cultivated fruit in Anatolia, as in the world. Due to the suitability of ecological conditions and diversity of cultivars, the land has an important production potential in terms of suitable vineyards for multi-purpose cultivation. The confluence of ecological harmony, varietal diversity and cultural heritage have allowed for the emergence of local products (the production of wine, table and dried grapes, and pickled leaves) specific to different regions. At the same time, the old tradition of grape cultivation in Anatolia paves the way for high quality products that can compete in the global market.

Vitis vinifera $\mathrm{L}$. is a species that can be grown economically in the big part of Turkey. In areas where culture vine can not be grown commercially, other species like Vitis labrusca etc. can be cultivated, thus gaining economic value for domestic consumption. With this feature, fresh grapes and their products are indispensable resources for producers of all sizes.

In this review, the deep-rooted history of cultivated and wild grapevine, in Anatolian geography is examined within the framework of recent literature. The review also discusses the current viticultural situation of Turkey. 


\section{Botanical Classification and General Morphology}

Necessary information on the morphological structure and botanical classification of grapevine (Vitis vinifera L.) is given to explain the significance of grape cultivation in Anatolia, in the first part of the article.

Vitis vinifera $\mathrm{L}$. is classified in the genus Vitis within the Vitaceae family. The Vitaceae family, which includes approximately 900 species and is divided into approximately 14 genera, is predominantly distributed in tropical and subtropical regions (Galet, 1988).

The genus Vitis is classified into two subgenera, Muscadinia and Euvitis. The Euvitis subgenus, which includes the cultivated vine Vitis vinifera $\mathrm{L}$., is classified as the American and Asian group. While cultivated vine V.vinifera $\mathrm{L}$. is classified in the Asian group, species such as V.berlandieri, $V$. rupestris, $V$. riparia used as pure rootstocks are classified in the American group (Mullins et al., 1992). Botanically, Vitis vinifera L. is a perennial and woody species. Tendrils give the plant climbing ability. These clutching structures of shoots are located at nodes opposite of leaves and tend to wrap around objects they touch. In this way, the grapevine tries to reach the sunlight by climbing high trees in its natural environment. The cultivated vine plant, on the other hand, is grown on trellis, fences or any other support material due to the positive response of pruning.

Like most of the plant kingdom, the root system is the interface element between the vine and the soil. It supports the vine by fixing it in the soil and is responsible for the intake of water and nutrients dissolved in water. The root is also the storage organ for carbohydrates produced as a result of photosynthesis. These storage materials constitute the first food source of newly formed roots and shoots at the beginning of the vegetation period. It is also the organ where some plant growth hormones such as cytokines and abscisic acids are produced (Creasy and Creasy, 2018).

The first of the structures that make up the vine's shoot system is the stem. The term of the shoot, generally used to mean a one-year-old shoot or cane refers to the structure that forms at the beginning of every vegetation and generates buds, leaves, nodes, internodes, lateral shoots, clusters, tendrils and growing tip. In grafted grapevines, the grafting point, which is the conjunction area of rootstock and scion, can be found on the soil level. The part of the grapevine that provides the transportation of water, nutrients dissolved in water and photosynthesis products between the summer shoots above the soil level and the root is called the stem. Also, in the first periods of vegetation, the carbohydrates necessary for root and shoot development are provided from the nutrient stores in the body until the first leaves reach $2 / 3$ of their size. Especially in water stress during the vegetation period, the compounds stored in the stem are consumed instead of the nutrients dissolved in the water that cannot be taken from the root. Vines are divided into perennial main branches or arms over the stem height determined according to the cultivation purpose. Therefore, the above-ground organs of the vine consist of the trunk and arms, canes, and shoots according to age.

Grapevine leaves exhibit great variation depending on the species, variety, and growing conditions. Leaf size, depth of lobes, serrated margins or a rounded structure, hair density: all are specific ampelographic features used in variety identification. At the same time, leaves are organs that have important physiological functions in the establishment of photosynthesis, transpiration and carbon balance in the vine, the regulation of the microclimate in the canopy, and the establishment of the plant and soil water balance (Nicotra et al., 2011; Wang et al., 2019).

The grapevine flower consists of 5 sepals, 5 petals separated from the receptacle like a cap at flowering time, 5 stamens, 1 pistil and 5 small nectars (Keller, 2015). All these organs are located on the flower plate (receptacle) and are connected to the pedicel and the rachis. When conditions such as appropriate temperature, humidity, availability of plant growth regulators in the right amounts, sufficient availability of water, nutrients and photosynthesis products to maintain the metabolic activity of the vine are provided, berry set occurs. Every flower that has been successfully pollinated and fertilized turns into a berry, and the other flowers fall off (Mullins et al., 1992). 


\section{History}

One of the most important milestones of human history is the domestication of plants and plant breeding. Domestication is a genetic selection process that transforms wild species into specialized crops according to desired characteristics by changing their morphological and genetic characteristics. Until recently, humanity has systematically or coincidentally improved plants, selected and developed new varieties in line with their own needs.

Grapevine domestication has been linked to the discovery of wine, occurred about 8.000 years ago (Unwin, 1991). Evidence of advances in winemaking techniques in the near eastern and northern Mesopotamia during the Neolithic period confirms this (McGovern, 2003; Forni, 2012).

Although the domestication centre of the grapevine is a long-contemplated subject, there is a consensus among archeologists and historians suggesting that the grapevine was distributed from Transcaucasia, which covers the borders of present-day Armenia, Georgia and Azerbaijan, together with north-eastern Anatolia. The region has been considered for a long time as the domestication centre for viticulture with the earliest examples of winemaking (McGovern, 2003; This et al., 2006; Maghradze et al., 2020). However, earlier, it was argued that the cultivation of vines for winemaking originated in the mountainous region between the Black Sea and the Caspian Sea, on the borders of the modern states of Turkey, Syria, Iraq, Iran and the former Soviet Union (Billiard, 1913; Johnson, 1989; Levadoux, 1956; Negrul, 1960; Ramishvili, 1983; Unwin, 1991). Even though the theories on the exact geographical location of where the grapevine was domesticated alter over time, Transcaucasia, as well as Anatolia, play a very prominent role in the domestication and distribution of Vitis vinifera ssp. Sativa and Vitis vinifera ssp. Sylvestris (McGovern, 2003; Vouillamoz et al., 2006). As indicated by various studies, the rich variety/genotype diversity in Anatolia (where includes parts of Northeast Anatolia, Western Anatolia, Central Anatolia, Mediterranean, Marmara, and Eastern Anatolia and Turkey's Thrace region in terms of geography) confirms today's Turkey as one of the geographical areas in which domestication first occurred (Arroyo-García et al., 2006; Ergül et al., 2011; Eyduran et al., 2016; Hizarci et al., 2012; Karataş et al., 2014; Kök et al., 2018; Korkutal et al., 2018; Yılmaz et al., 2020).

Therefore, considering the agricultural efficiency of other species such as wild oleaster populations and cultivated olive trees (ArroyoGarcía et al., 2006), cereals (Zeder, 2011) in the region, academic studies have explored the existence of wine production with wild Vitis populations in the Pre-Pottery Neolithic period (10.000-6.500 BCE) before domestication. As Unwin (1991) reported, the first wine production possibly occurred in the core of the Sumerian, Akkadian, Assyrian and Babylonian empires, and also to the east of the heartland of the Hittite empire in what is now Turkey. Moreover, the archaeological and historical evidence indicates that primitive domestication events may have occurred early in the Near East, even though the wild grapevine populations spread to Europe and Asia during the Neolithic period, (ArroyoGarcía and Revilla, 2020).

There are several difficulties in finding any conclusive evidence regarding the growing of grapevine and winemaking from culture or wild vine from 10.000-12.000 years ago. The first condition is mastery in the production of pottery for wine production and storage. Therefore, it should be taken into account that this art emerged in the Pre-Pottery Neolithic period or before. Another issue is that in wine production, direct use of seed is not necessary as it is in making beer or bread. Thus, pips are seen as waste and transformed organically since they are not carbonized by cooking (McGovern et al., 2017). On the contrary, barley and wheat (einkorn and emmer) grains, which are poured near the stoves during bread making and carbonized by burning, provide definitive evidence for the production and consumption characteristics of the Pre-Pottery Neolithic period. On the other hand, the requirement that the vine shows at least three growth periods for its product meant that the grape would be a rarer commodity than wheat and barley. This was a challenge in that period (McGovern et al., 2017).

As McGovern and his colleagues have shown, the earliest well-proven evidence of wine production comes from 7.000 BCE in China and secondly an archaeological site from 5.400-5.000 
BCE called Hajji Firuz Tepe located in the northwestern part of the Zagros Mountains, extending west of present-day Iran and Azerbaijan (McGovern et al., 2017).

The archaeological sites, especially Göbekli Tepe but also Hallan Çemi, Demirköy, Körtik Tepe, Cafer Höyük, Çayönü and Nevali Çori, have the potential to change everything known about the human history (Figure 1). These sites were located among the periods of 12.0008.000 BCE between the southern Levant, Central Fertile crescent and Central Anatolia regions (Zeder, 2011).

In this period, it is reported that human communities in the northern Fertile Crescent used various different species at the same time, taking into account the regional differences. For example, Hallan Çemi, the oldest pre-pottery Neolithic site in Anatolia, became prominent in the late epipalaeolithic period (12.500-9.500 $\mathrm{BCE})$ as a location where species such as sea clubrush (Bolboschoenus maritimus), largeseeded legumes, almonds (Amygdalus sp.) and pistachio (Pistacia sp.) were used extensively (Piperno et al., 2004; Savard et al., 2006).

Among them, Göbekli Tepe, a Neolithic archaeological site near the city of Şanlıurfa in Southeastern Anatolia, has provided extraordinary information about the emergence of cult and feasting traditions in Neolithic societies. The ongoing excavations have proven that grapes were grown locally in the region for wine production and the first settled agriculture was performed in Göbekli Tepe, which is dated to the pre-pottery period (Schmidt, 2010). Göbekli Tepe is located in the region where the grape was endemically spread and dometicated (Jackson, 2014). Overall, the emergence of wine, molasses and other grape products in the Near East is thought to be related to the presence of Vitis vinifera in this region. Data from the Diyarbakır Körtik Tepe excavation (Özkaya and San, 2007), which was also dated 10.000 BCE, suggest that the existence of wild grapes in Southeastern Anatolia started from these dates (Dietrich et al., 2012; Uhri, 2017).

Under this social life of the early Neolithic period, the existing literature poses the possibility that local people did not limit their alcohol consumption habits with beer but made and consumed wine as a part of their daily diet (Dietrich et al., 2012; McGovern et al., 2017). Nevertheless, it should be noted that the alcoholic beverage, which was called wine for the Neolithic period, is quite different from today's modern perception in terms of quality and standards. This product should also be considered as a product with different additives such as spices, honey, and it was diluted as in the ancient Hellenic and Roman periods of Anatolia (Laflı, 2017).

\section{Geographical Distribution}

\section{World}

Cultivated grapevines (Vitis vinifera spp. Sativa) are known to have been domesticated

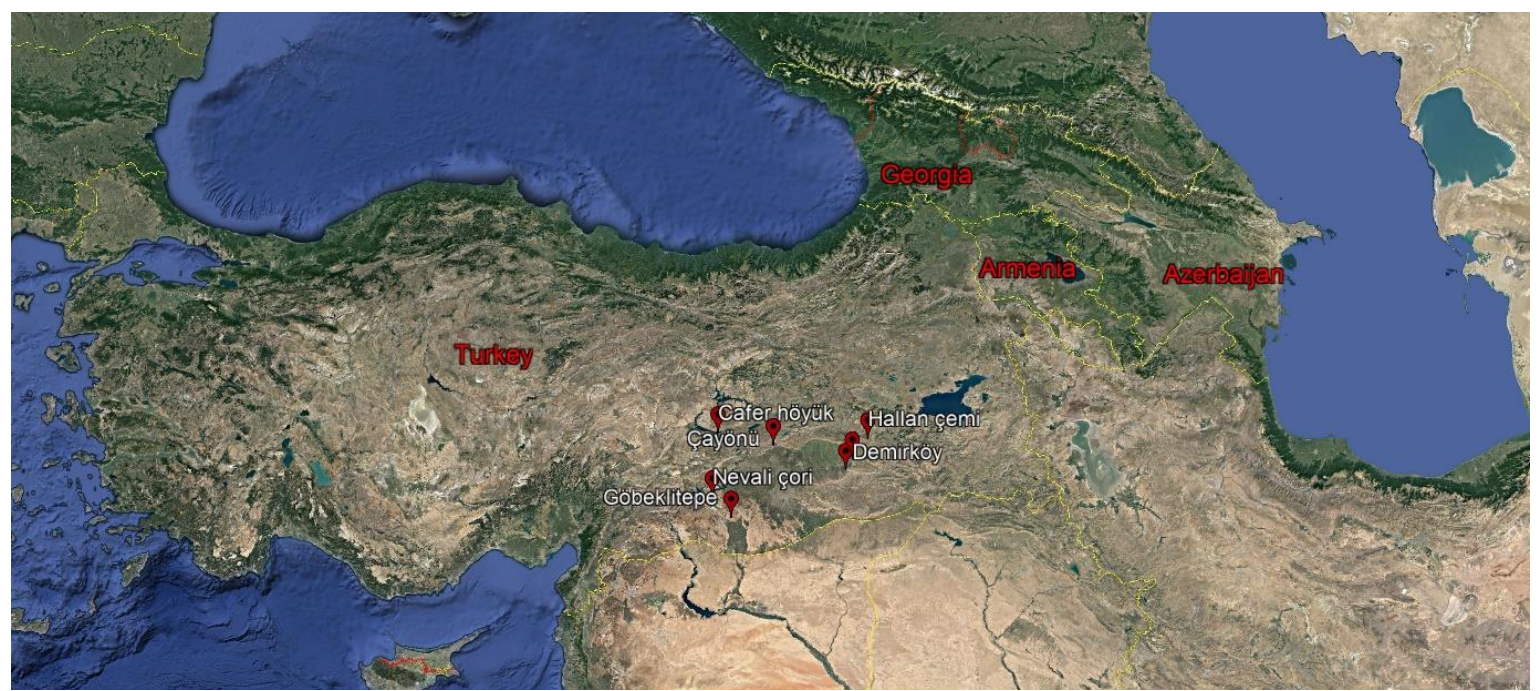

Figure 1. Locations of some important archaeological sites from the intersection of southern Levant, Central Fertile crescent and Central Anatolia regions (Google, 2021). 
from wild populations of Vitis vinifera spp. Sylvestris (Levadoux, 1956). These wild populations which are dioecious plants still can be found along with riverbank forests from the Atlantic coast of Europe to the western Himalayas (Zohary and Hopf, 2000; Smith, 2008). Many studies describe the links between the present presence of these wild populations and vinifera transformations (Arroyo-García et al., 2006; De Mattia et al., 2008; Grassi and ArroyoGarcia, 2020; Marvelli et al., 2013; Riaz et al., 2018).

Culture of grapevine is largely limited to regions characterized by the Mediterranean climate and transitional climates. Growing in colder, warmer or more humid regions can be done within the limits of meso and microclimatic conditions and variety characteristics. On the other hand, regional changes due to the climate crisis and different cultivation practices tend to change these borders. Today, commercial cultivation can also be done in the continents of North America, South America, South Africa, Australia and New Zealand, even in tropical regions where the vine plant is evergreen, especially for table varieties.

Establishment of the earliest vineyard of V.vinifera $\mathrm{L}$. was realized by changing the climate in the origin regions, increasing the temperatures and becoming more humid than before. The relative climatic drying that started in 2.000 BCE made the culture vine adapt to the current semi-arid climate. It is known that Vitis vinifera $\mathrm{L}$. has been domesticated in at least two different regions, one in the Near East and a second one in the western Mediterranean region that gave rise to many of the Western European cultivars. The analysis of genetic relationships between wild and cultured populations supports the existence of an important contribution of wild sylvestris germplasm from the Near East and Western Europe to the origin of current Eurasian cultivars (Arroyo-García et al., 2006).

The distribution range of the populations Olea europaea species, which is another important plant for humanity, and wild oleaster populations, is similar to the grapevine. The existence of western olive cultivars carrying chlorotypes that are only found in western oleaster populations also led to propose a multilocal origin of olive cultivars (Besnard et al., 2018).
Over time, the dispersal of locally grown varieties through colonization movements, both natural and human-made crosses and mutations resulted in an unimaginable diversity of many vinifera species. Although it is estimated that about 10.000 grape varieties are grown commercially today, it is reported that 5.000 varieties are more realistic after the synonym and homonyms determined by DNA analysis are eliminated (This et al., 2006). It is known that many cultivars are highly related to each other as synonyms and homonyms (Keller, 2015).

\section{Anatolia}

After the domestication of wild Vitis populations, Vitis vinifera L. varieties and wild species spread over Anatolia. Since then, they can be found in different Anatolian sub-regions.

Today from Thrace and Aegean regions to Central and Eastern Anatolia, the agricultural zones of Turkey are generally suitable for commercial production of grape, wine and grape-related products in terms of climate, soil characteristics and varietal diversity. The extreme humid and rainy regions of the Eastern Black Sea coasts may be an exception to this situation. In this region, Vitis labrusca varieties are grown and consumed with the family farming concept.

The first and largest grapevine field gene bank in Turkey which was planted by Tekirdağ Viticulture Research Institute currently contains 1439 grape varieties/genotypes (Uysal et al., 2020). With this project, besides ampelographic characterization, a leaf herbarium was also created. All the data obtained were recorded in the database and started to be published on vitis.tagem.gov.tr web page as of 2021.

\section{Anatolian Climate}

Across Turkey, the Mediterranean climate impact is felt over a wide area. Following the Mediterranean coastline beginning in the Southern Amanos Mountains and extending to the Bakırçay basin in the Aegean region, the effect of the Mediterranean climate is observed. The Lakes region lying behind the Mediterranean region and the Niğde-Kayseri location extending to the north of the Central Taurus Mountains, and the Inner Aegean agricultural region located in the inner parts of the Aegean Region, also 
have a Mediterranean climate transition feature. Although it is located in the Gaziantep-Şanlıurfa location and further inland in the plateau areas that are inserted from the eastern part of the Amanos Mountains to the southeast, the Mediterranean climate transition feature is also observed in the Upper Euphrates part. However, it can be said that this region is a little more arid (Turkes, 2019).

The coastal areas of Thrace, which is surrounded by the Aegean, Marmara and the Black Sea, are under the influence of the sea climate and the inner part is under the influence of the continental climate. In this region, the Mediterranean transition climate from the North Aegean to Istanbul is observed. Along the coast in the south, the typical Mediterranean climate prevails. The north of the region and its coasts are more humid (Papp and Sabovljević, 2003).

In addition to other regions, Black Sea region represents a humid-temperate climate and continental inland climates. The Black Sea region is characterized by a mid-latitude temperate climate with a low-level drought probability and risk. In contrast to other regions in Turkey, the Black Sea region is an exception for not being influenced by mid-to-high degree drought probability and drought risk.

According to Koppen-Geiger climate classification, 10 sub climates under 3 main were determined in Turkey (Figure 2). The most widespread is the temperate mid-latitude climate (C) in winters and the Csa climate type, which corresponds to the typical Mediterranean climate, among these climate types. $\mathrm{Cfa}$ and $\mathrm{Cfb}$ sub-climate types correspond to the Black Sea climate region with precipitation in all seasons and spread throughout the Black Sea belt. The second most common climate type and the continental climate, cold and temperate midlatitude climate (D), is seen in the high parts of central Taurus Mountains, Central Anatolia and almost all of Eastern Anatolia. The lowest in the area corresponding to the amount of precipitation in Turkey's arid climate type (B), is the particularly large footprint in Central Anatolia (Öztürk et al., 2017). Although some viticulture climate indicators of some important cities are seen for long years in Table 1 when the values of recent years are considered one by one, a general temperature increase can be seen with a little decreasing total precipitation but a change in rainfall periods.

With this climate diversity forming different rainfall regimes and the effects of the climate crisis, the characteristics of annual precipitation are seasonally changing. Moreover, the increasing frequency of extraordinary weather events stand out as the climate effects that make vitiviniculture difficult in the coming period.

\section{Statistics and Economy}

\section{World}

As the statistics of the International Organisation of Vine and Wine (OIV) shows, there is a total of 7.4 mha vineyards in the world. However, vineyards are not equally distributed; 5 countries represent $50 \%$ of the global vineyard areas. While total grape production is $77.8 \mathrm{mt}$.

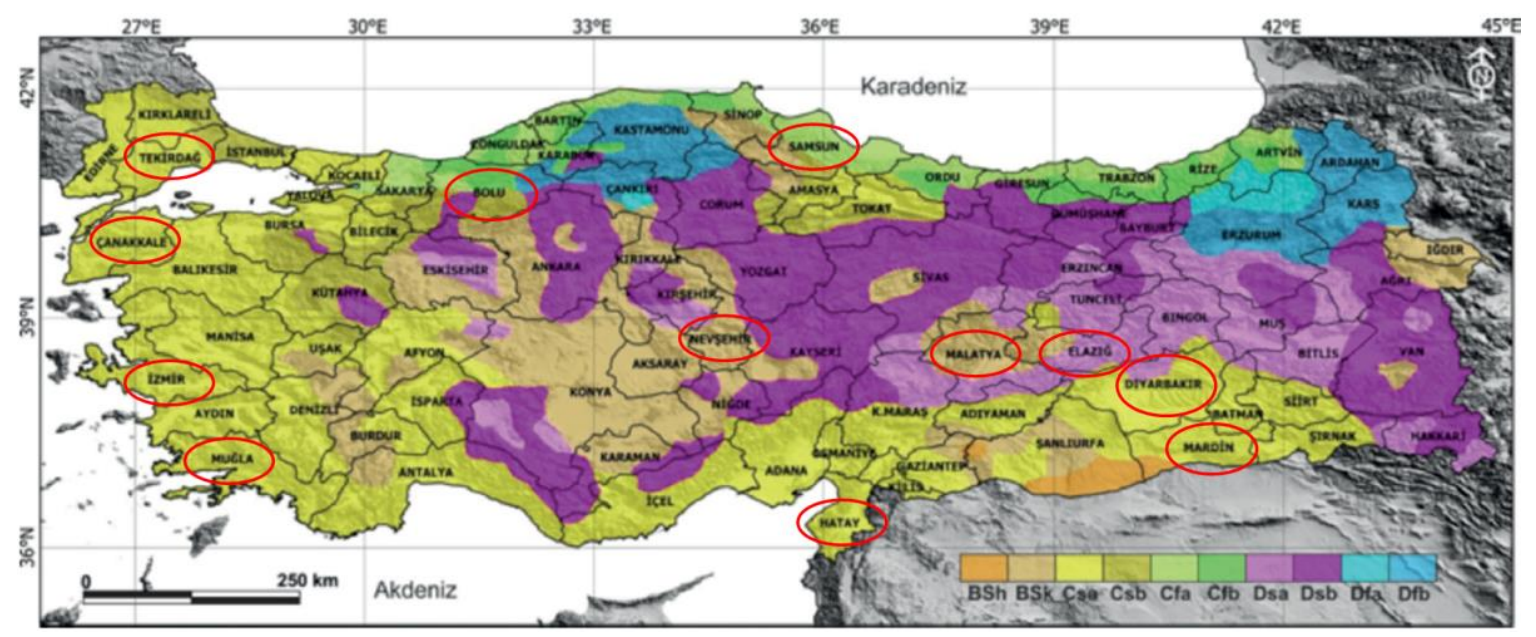

Figure 2. Climate types of Turkey according Koppen-Geiger climate classification (Modified from Öztürk et al., 2017). Red circles represent some of representive cities where viticulture is performed. 
Table 1. Long years' viticulture climate indicators of some major cities in Turkey

\begin{tabular}{|c|c|c|c|c|c|c|c|}
\hline Provinces & Years & $\begin{array}{l}\text { Winkler } \\
\text { index } \\
\text { (WI-GDD) }\end{array}$ & $\begin{array}{l}\text { Hydrothermic } \\
\text { index } \\
(\mathrm{Hyl})\end{array}$ & $\begin{array}{l}\text { Night } \\
\text { cold } \\
\text { index } \\
\text { (Cl) }\end{array}$ & $\begin{array}{l}\text { Growing } \\
\text { season } \\
\text { temperatures } \\
\text { (GST) }\end{array}$ & $\begin{array}{l}\text { Branas Heliotermic } \\
\text { index } \\
(\mathrm{BHI})\end{array}$ & References \\
\hline Tekirdağ & $1939-2018$ & 1887.00 & 3437.63 & 16.00 & 18.99 & 6.24 & (Candar et al., 2019a) \\
\hline Çanakkale & $1928-2017$ & 2073.00 & 2532.12 & 15.90 & - & 8.13 & (Candar et al., 2019b) \\
\hline Samsun & 1960-2012 & 1832.00 & 4054.00 & - & - & 3.0 & (Köse, 2014) \\
\hline İzmir & $1938-2018$ & 2700.00 & 2065.25 & 18.60 & 22.86 & - & \\
\hline Muğla & $1928-2018$ & 2184.00 & 3068.26 & 15.20 & 20.40 & - & \\
\hline Hatay & $1940-2018$ & 2829.00 & 5415.37 & 21.10 & 23.47 & - & \\
\hline Nevşehir & $1959-2018$ & 1338.00 & 2434.41 & 10.20 & 16.37 & - & \\
\hline Malatya & $1929-2018$ & 2271.00 & 2160.99 & 15.50 & 20.81 & - & (Candar et al., 2019a) \\
\hline Elazığ & 1938-2018 & 2178.00 & 2166.68 & 14.60 & 20.37 & - & \\
\hline Diyarbakır & $1929-2018$ & 2787.00 & 2132.52 & 15.90 & 23.27 & - & \\
\hline Mardin & $1941-2018$ & 2760.00 & 2217.48 & 20.70 & 20.70 & - & \\
\hline Bolu & $1929-2018$ & 1161.00 & 3744.93 & 9.40 & 15.53 & - & \\
\hline
\end{tabular}

$57 \%$ of the production is used for wine production, whereas $36 \%$ for table grape and $7 \%$ for raisin (OIV, 2020).

As production areas in the world, Spain, France, Italy, China and Turkey stand out as the first of five major grape-producing countries. When these countries are assessed in terms of the amount of grape sorting, the ranking slightly changes; as the first China, followed by Italy, the USA, France, Spain and Turkey. France and Spain stand out for the production of wine grapes. The production of table and wine grapes in Italy is intensive. Grape production in the USA and China is balanced for all three product types. Turkey stands out for both table and dried grapes production. Argentina, Chile, the Republic of South Africa, New Zealand and Australia are countries where viticulture is developed in the Southern hemisphere (OIV, 2020).

\section{Turkey}

Turkey has 416.907 ha of vineyards, with a decreasing trend in the vineyard areas in the last 20 years. As the result of the privatization of the state monopoly (TEKEL), which served as regulatory mechanism for the unit price of grapes, there is a growing tendency among vignerons to uproot their vineyards. As the grape cultivation is losing its economic viability, more and more farmers have stopped cultivating grapes and continued with other crops. According to recent statistics, there is a total production of 4.199,999 tons of fresh grapes in Turkey (TUIK, 2021).
Turkey is well-known for its seedless raisin production in the world and, although it has changed over the years, ranks first or second in terms of production and first in terms of exports. The Aegean coast of Turkey is the most prominent area in the production of raisins (Table 2).

The Aegean region ranks first in terms of both area and production. This region has $33.69 \%$ of the vineyards and $53.27 \%$ of the grape production. The average yield of raisins per decare has exceeded $1000 \mathrm{~kg}$ in many areas in the region. All of the seedless raisin production belongs to the Sultani Çekirdeksiz and Yuvarlak Çekirdeksiz grape varieties. About $85 \%$ of the total raisin production is imported by the European Union (EU) countries, especially the Netherlands and Germany and the United Kingdom. Some districts of Manisa and Denizli are the locations that make intensive production in table grapes and evaluate their products in foreign markets. For table use, Sultani Çekirdeksiz grape varieties such as Superior Seedless, Trakya Illkeren, Michele Palieri, Red Globe and Crimson Seedless are cultivated. In recent years, important developments have taken place in terms of wine production. Boutique wineries have been established in large areas in the districts of Denizli, Izmir and some districts of Manisa.

Southeastern Anatolia takes second place in terms of area with $23.93 \%$, production amounts are almost the same as the Mediterranean region with $13.69 \%$. Elazığ, Diyarbakır, Mardin, Gaziantep, Kilis and Malatya 
Table 2. Grape production areas and quantities in 2020 according to usage purpose.

\begin{tabular}{|c|c|c|c|c|c|c|c|c|}
\hline Region & Table & & Wine* & & Dried & & Total & \\
\hline & $\begin{array}{l}\text { Area } \\
\text { under } \\
\text { vine(ha) }\end{array}$ & $\begin{array}{l}\text { Production } \\
\text { (ton) }\end{array}$ & $\begin{array}{l}\text { Area } \\
\text { under } \\
\text { vine(ha) }\end{array}$ & $\begin{array}{l}\text { Production } \\
\text { (ton) }\end{array}$ & $\begin{array}{l}\text { Area } \\
\text { under } \\
\text { vine(ha) }\end{array}$ & $\begin{array}{l}\text { Production } \\
\text { (ton) }\end{array}$ & $\begin{array}{l}\text { Area } \\
\text { under } \\
\text { vine(ha) }\end{array}$ & $\begin{array}{l}\text { Production } \\
\text { (ton) }\end{array}$ \\
\hline Mediterranean & 46.89 & 485.28 & 2.40 & 25.04 & 7.68 & 64.02 & 56.98 & 574.35 \\
\hline Eastern Anatolia & 21.05 & 111.03 & 5.15 & 23.81 & 3.68 & 24.67 & 29.89 & 159.51 \\
\hline Aegean & 48.52 & 822.32 & 14.38 & 140.73 & 77.53 & $1.274,29$ & 140.44 & $2.237,35$ \\
\hline S.E Anatolia & 52.11 & 299.84 & 19.33 & 122.15 & 28.32 & 152.97 & 99.77 & 574.97 \\
\hline Black Sea & 3.25 & 23.17 & 4.69 & 38.40 & 0 & 0 & 7.95 & 61.575 \\
\hline Marmara & 13.89 & 163.66 & 6.44 & 62.65 & 20 & 288 & 20.36 & 226.61 \\
\hline Central Anatolia & 38.08 & 203.67 & 11.26 & 75.18 & 12.14 & 86.75 & 61.49 & 365.61 \\
\hline Total & 223.83 & $2.109,00$ & 63.68 & 487.99 & 129.39 & $1.603,00$ & 416.90 & $4.199,99$ \\
\hline
\end{tabular}

*musts \& juices included in wine values (TUIK, 2021).

provinces are the ones with important vineyards in the Eastern and Southeastern Anatolia Regions. The main varieties of raisins with seeds in this region are Besni, Rumi Kerküş, Dimrit, Sergi Karası and Antep Karası varieties. Especially with seeded-dried varieties, internationally known high-quality wine varieties such as Öküzgözü and Boğazkere are grown.

The Mediterranean region is especially important for early grape cultivation under greenhouse. With Yalova İncisi and Trakya Illkeren, Superior Seedless varieties, early crops can be obtained at the end of May. Plateau viticulture is also relatively carried out in the Mediterranean region.

The Thracian section of the Marmara region, on the other hand, is the hub mostly for wine grape varieties. Table grape varieties ripen in the middle and late seasons on the Anatolian side of the region. There have been boutique wineries established with significant investments in the Tekirdağ, Edirne, Kırklareli provinces and the Gelibolu peninsula. Smaller manufacturers located in the Thrace region, which sell fresh grapes to privately owned factories for wine production, represent a wine production habit specific to Turkey. As the result of the growing number of small scale and quality-oriented production in the Thracian part of Turkey, there is an increase in cultivating varieties known as the noble French ones, especially Cabernet Sauvignon, Merlot, Shiraz, and Sauvignon Blanc, along with local varieties.

Overall, a ratio of $50.21 \%$ of the total fresh grape production of Turkey is evaluated as table grapes. The rate of dried grapes is $38.17 \%$. A ratio of $11.62 \%$ is used substantially in wine and obtain various food products (Figure 3 ).
The grape's other evaluation products include fresh leaf, molasses (pekmez), hardaliye, sucuk, jam, köfter, bastık, samsa, fruit pulp and other local products. They are mostly consumed in the domestic market.

\section{Uses}

Grapevine products are one of the most diverse among other agricultural products. This situation is related not only to geographical and climatic characteristics but also to the culture and society in which grapevine is cultivated (Unwin, 1991). In addition to the use of grapes for wine, table and raisin, there are also some other forms of evaluation specific to Anatolia.

Apart from the fruit itself, the other edible organ of the vine plant is its leaves. Primarily Tokat province located inner of Black Sea region, Thrace and Aegean regions are producers of vine leaves. Narince, Sultani Çekirdeksiz and Yapıncak varieties are suitable for fresh and brined consumption in terms of the morphological features and flavours of their leaves. Cooking with grape leaves is quite widespread in the cuisines of various regions of Turkey.

Molasses is yet another grape product amply produced in Turkey. Despite its high sugar content, molasses is considered as an important food in terms of carbohydrates and minerals it contains. Molasses is produced in almost all regions, and particularly solid molasses kinds, differ in terms of taste, consistency and colour. In the production of sweet-liquid molasses with the traditional method, grape must is added to molasses soil (a type of white coloured soil containing $50-90 \%$ lime. It is used to clarify the syrup in molasses production) and boiled. Then, 
A

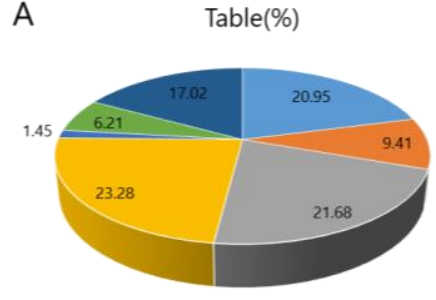

Table(\%)

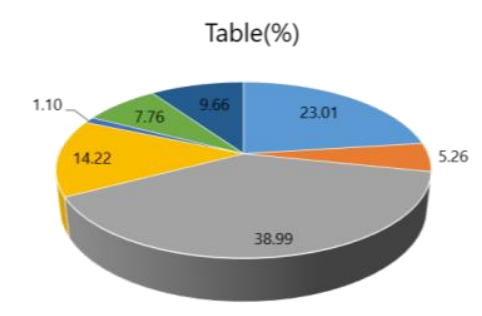

B

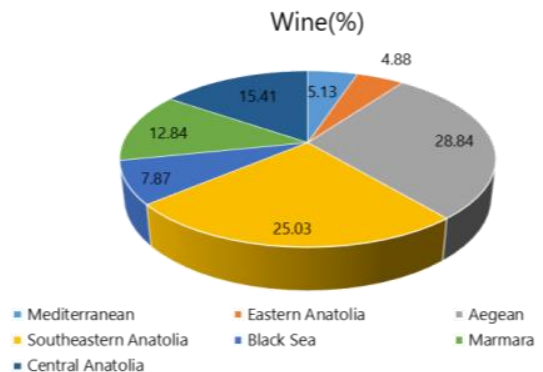

Wine(\%)

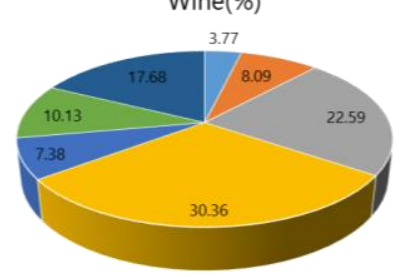

Wine(\%)

- Central Anatolia

Figure 3. Distribution of vineyard area and production percentages by regions according to the purpose of use (TUIK, 2021). A represents area under vines(\%), B represents production(\%), musts \& juices included in wine values.

clear sweet must is obtained by filtering. Finally, the must is boiled over the fire in open cauldrons (Gülcü, 2010).

The recipe of Bulama (solid molasses) also differs between regions due to production methods and the variety of production materials. Bulama is made by adding the juice of previously boiled Çöven (Gypsophila L.) roots to liquid molasses. This addition allows the colour to lighten and solidify (Gülcü, 2010).

Hardaliye is the traditional product of the Thrace region, produced from red and aromatic grape varieties, especially Papazkarası, through lactic acid fermentation. It is produced by adding crushed mustard (Sinapsis alba) seeds, potassium benzoate and cherry leaves to grape must. The mixture, which is kept at room temperature for 15-20 days without air, is filtered and kept in cold (Gülcü, 2010). The final product may differ in terms of taste, aroma and colour due to the nature of traditional production methods. Hardaliye has been produced in Thrace cities such as Kırklareli, Edirne, Tekirdağ and Gelibolu for ages.

Pestil or Bastık (dried berry pulp), is produced by boiling grape must or liquid molasses with wheat flour or starch. The mixture is then laid in a thin layer $(0.5-2.0 \mathrm{~mm})$ on a flat surface and dried (Figure 4).

Sucuk (Köme, Orcik), is obtained by passing a rope through especially walnuts, almonds, hazelnuts and pistachios, dipping into the slurry previously described for making pestil and drying.

Köfter, is produced by boiling the molasses soil with grape must for a short time. Later, a certain amount of flour or starch is added to the mixture. It is cooked until it acquires the consistency of dough. It is poured on high sided trays and left to dry in the sun. Its surface is expected to turn into a sweet and white colour.

To prepare Saruç, after the black grapes with large berries are washed and cleaned, they are divided into two and made semi-dry in the sun (Uysal Seçkin and Taşeri, 2015). A half walnut is placed between the berry and kept in a closed container. In the following days, it is strung on ropes and dried. Only Karaerik (synonym Cimin Üzümü) grape variety is considered suitable for Saruç, for its very big black berries and unique flavour in the province of Erzincan (Uysal and Candar, 2017).

Samsa is a local product that belongs to the province of Kahramanmaraş. It is made from the Kabarcık grape variety, by turning the molasses into a pulp and filling it with crushed walnuts with triangular folding.

To make Ravanda, the grape berries are kneaded by hand and turned into a slurry. This slurry is extracted by passing through a metal strainer. When it is diluted a little and reaches the consistency of a soup, it is put into cloth bags and hanged high and left to strain. The extracts taken from the straining bags are kept in flat trays for 3-4 days. It is stored in a jar. Water is added to it and turned into syrup before 


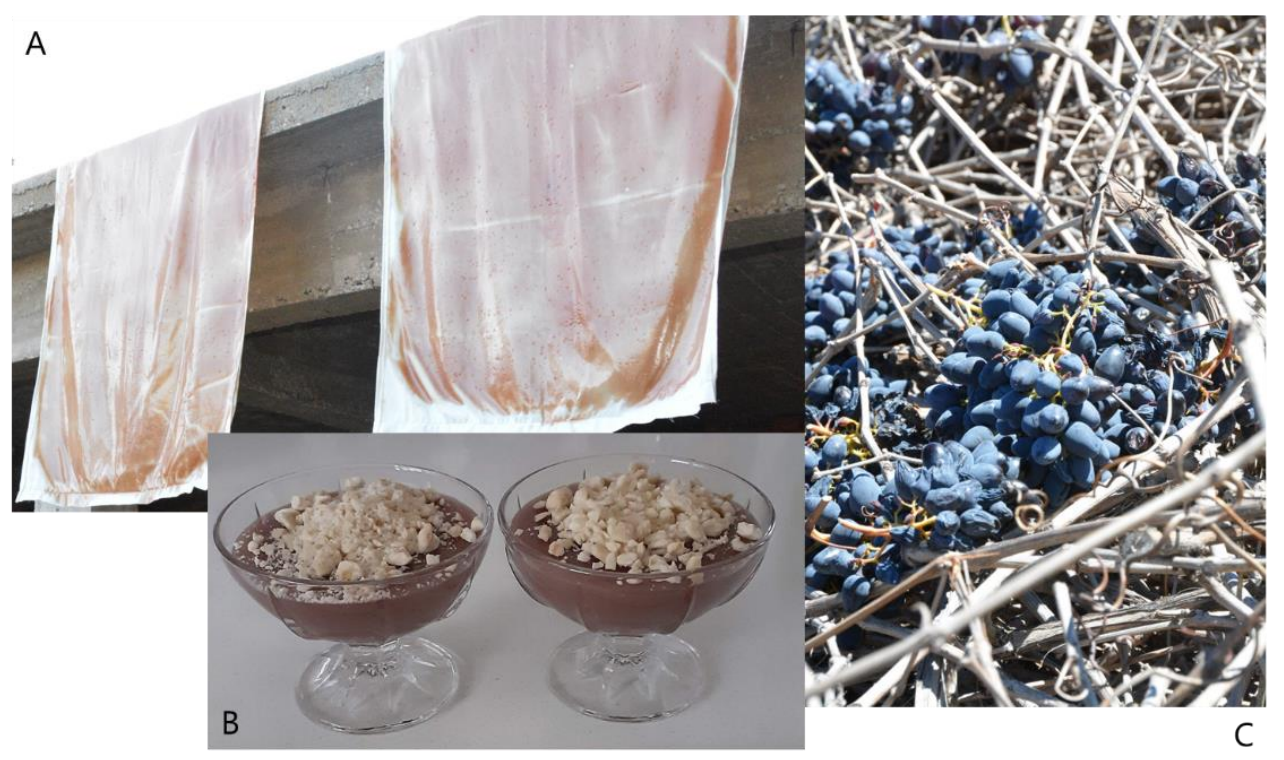

Figure 4. Samples of some local usages of grapes (Photo credits Tamer Uysal). A represents Pestil (dried fruit pulp), B represents Pepeçura, C represents a sample of open-air drying of Banazı Karası grape variety.

consumption (Gülcü, 2010).

Hapısa is made by cooking molasses, water, flour and starch over the fire until it reaches a paste-like consistency. It is consumed with products such as walnuts and dried figs.

Pepeçura is only prepared with Vitis labrusca var. Isabella (synonym Kokulu Üzüm, Çilek Üzümü) grapes. It is made from grape must, water, wheat flour and starch or cornflour. The mixture is cooked to the consistency of jelly (Figure 4).

Unlike the above-mentioned products, Banazı karası, Göğ Üzümü, Margaz grape varieties can be used by drying naturally in open air or barn, cave etc.

These are only some of the grape products that we can list in this article. To understand how rich and deeply rooted grape cultivation is in Turkey. Comprehensive studies must be conducted on the culinary traditions of the various regions of the country.

\section{Cultivars}

As previously mentioned, Tekirdağ grapevine field gene bank, established by the Tekirdağ Viticulture Research Institute, hosts 1439 grape varieties/genotypes. Many of them are consumed locally in limited areas. However, there are some varieties that are widely used in the wine industry of Turkey, especially due to their quality potential to compete with international varieties. This section of the article lists some of these grape varieties with their primary characteristics.

Bornova Misketi is one of the local grapes that is praised by the wine industry of Turkey. It has thick skin and a high yield of must. Bornova Misketi is a variety that has the characteristic tastes and aromas of the muscat group. The variety produces highly aromatic, fresh, easydrinking golden yellow, dry and semi-dry white wines. It can contain flavours such as mint, honey, citrus, bergamot and melon. It is grown in the Aegean region, especially in the province of Izmir.

Emir variety is one of the quality wine varieties of Central-South Anatolia. Emir variety produces elegant wines with green-yellow or light yellow colour, high acidity with no predominant fruit flavours. Also, the most prominent fruit taste is the fine green apple. Wines have a taste that carries mineral and fresh flavours. Green fruit flowers (raw lemon, green plum) are among the most common aromas in Emir. Sometimes this flavour can appear as ripe lemon. It is also suitable for making sparkling wine.

Narince variety, apart from its use for leaves, is the best quality white wine variety in the inland Black Sea region. Semi-dry wines with their special aroma can also be produced from Narince. It is also used in blended wines made with other local varieties such as Emir and Sultaniye. Narince can also be adapted to Southern Thrace, Çanakkale and Northern 
Aegean, which are approximately at the same latitude as around origin location Tokat.

Hasandede (synonym Sungurlu) is one of the varieties grown in Central Anatolia for centuries. Even if yield and quality losses are experienced due to old plantations, the interest in the variety is increasing. Its wines are bright, clean and pale lemon in colour. It has around 12$13 \%$ alcohol, slightly lower acidity.

Yapıncak variety is important for its bright gold colored and fruity white wine with lemon and nectarine aromas. Unlike Narince, which is widely planted for its leaf and table consumption, Yapincak is famous for its thinbodied and highly mineral wine. This Tekirdagoriginated variety spreads throughout the Gelibolu peninsula and the entire coastal part of the Marmara region.

Adakarası is a grape variety grown especially in Avşa and Marmara Island. The grape of Adakarası grape is large and its skin is thick. It exhibits properties that can be used in adaptation studies to drought caused by the climate crisis. Its wines are red in colour, high bodied, with distinctive red currant, wild strawberry and cherry aromas and suitable for ageing.

Boğazkere is a very valuable wine variety due to its high tannin content, astringency and spice aromas. This grape variety belongs to the region covering the provinces of Elazığ, Malatya, Diyarbakır and Gaziantep. It produces the best quality in calcareous, gravelly, red coloured soils. Dense tannin content increases the usage possibilities in blends made with Öküzgözü. The variety contains black and red fruits such as black mulberry, blackberry, raspberry, cherry, morello cherry, as well as thyme, white pepper and clove spice aromas especially in aged monocepage wines.

Öküzgözü is another local variety that comes from the same region as Boğazkere. When used as a monocepage Öküzgözü exhibits high acidity and low alcohol profile. But the uniqueness of monocepage wines with plump bouquets is the prominent character of the variety. During ripening, the sugar rate is lower than other grapes. Although Öküzgözü has recently started to be grown in the Aegean and Mediterranean regions, the flavours of the wines produced from the grapes cultivated in these regions are less intense and less acidic.
Öküzgözü wines are in dark ruby red colour with aromas of blackberry, raspberry, cherry, sour cherry, cherry jam, black mulberry and raspberry.

Papazkarası is a red wine variety that originated Kırklareli and Edirne. It has been actively shows distribution in Turkey's Trace since ancient times. It gives high-quality wines with a unique bouquet, full and pleasant drink.

Karasakız (synonym Kuntra) is an old local grape grown in the Northwest Aegean, Southern part of Thrace regions, Çanakkale and especially Bozcaada (Tenedos) island. Berries are fleshy, juicy and dark in colour. It has low acidity. The variety produces very high tannin wines containing $12-13 \%$ alcohol and 5-6 $\mathrm{g} \mathrm{l}^{-1}$ acid. Although Karasakız is a grape variety that is traditionally used in cognac production, monocepage and blended wines also have a significant quality.

Kalecik Karası is a variety that has been grown in the region of Central Anatolia and the province of Ankara since the Hittites. Kalecik Karası wine is violet-ruby coloured, flavoured, full and balanced. It is weak in tannins but rich in fruit aromas. Cotton candy, strawberry, raspberry are the most typical flavours of Kalecik Karası wine.

Apart from those mentioned above, in addition to wine varieties such as Vasilaki, Foça Karası, Barburi and Şire local table varieties such as Çavuş, Beylerce, Tilki Kuyruğu and Hönüsü are the varieties that are dominant in the Anatolian geography.

Also, Emirali, Gönülçelen, Tekirdağ Misketi varieties produced by the Tekirdağ Viticulture Research Institute by cross-breeding are the table grape varieties that have not yet spread but have high potential. Similarly, Karamenüş, Yayla and 111-31 varieties selected by selective breeding from the Tekirdağ grapevine field gene bank are also high-quality wine grape varieties.

In recent years, number of local varieties started to occupy spots in Turkey's wine production scene. They are not only used for table wine production, but especially as the result of the increasing number of boutique wineries, it is proven that some of the local grapes of Turkey carry the potential for high quality wine. These varieties are mainly instrumentalized by wineries to translate characteristics of Turkey's soil, terroir, to international consumers. As there is world-wide interest in local tastes, producing wine with the 


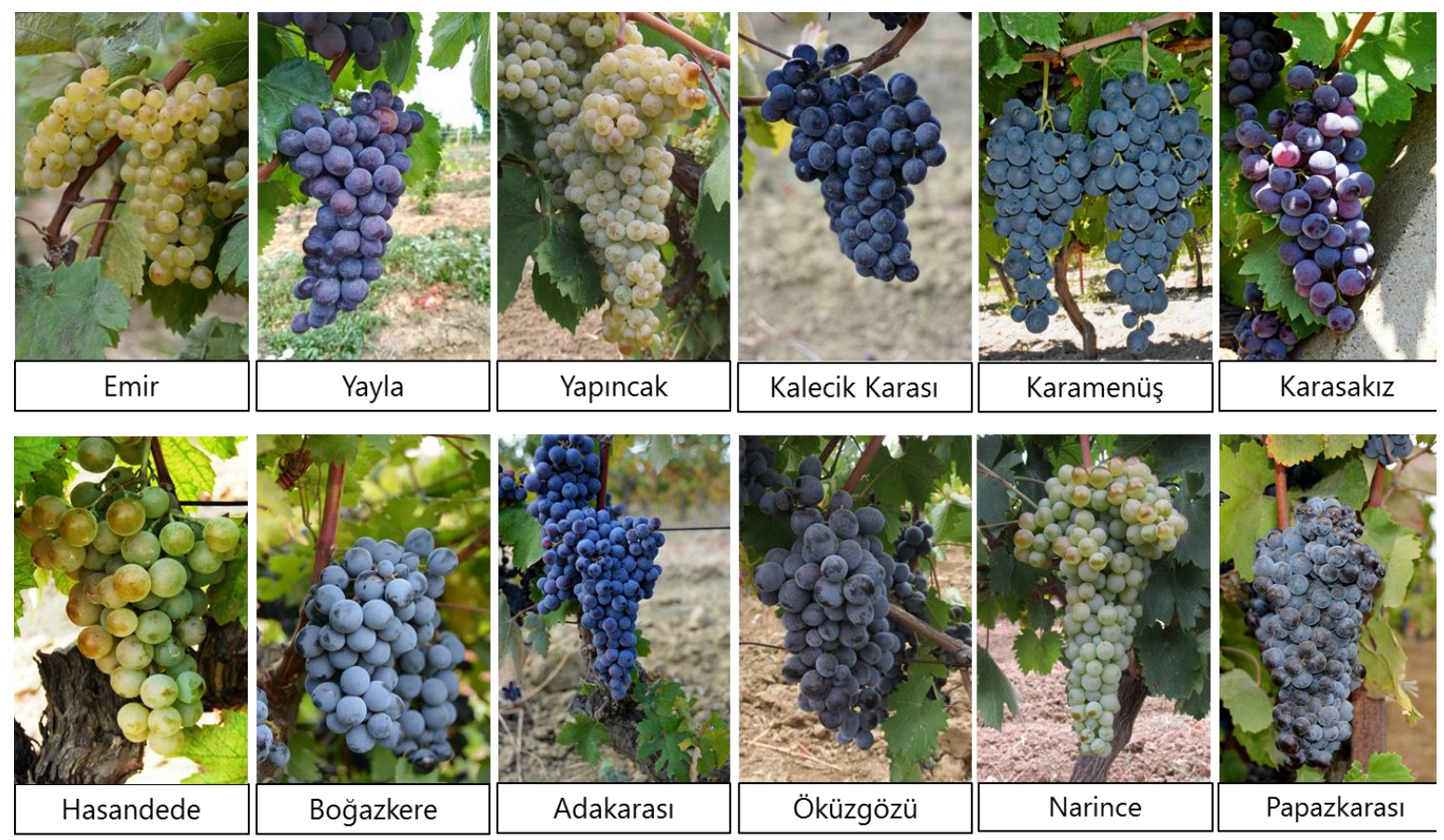

Figure 4. Samples of some local usages of grapes (Photo credits Tamer Uysal).

country's local grapes has created an opportunity for winemakers in Turkey to advertise their bottles in the international arena.

\section{Culture, Arts and Society}

The vine plant has been an important element in Anatolian culture throughout history. It has been the theme of folk songs, riddles, proverbs, idioms, tales and legends in folk literature. In Turkish culture and mythology, the grape is the symbol of beauty, fertility, blood, soul, love and health (Şenocak, 2008).

Dionysus, one of the most powerful figures of viticulture, wine-growing, agriculture and nature, is a god known since 2.000 BCE, albeit with different names and faces throughout the Mediterranean, including Anatolia, Egypt and North Africa (Akgezer, 2018).

In the Hellenistic world, the idea that Dionysos came from Thrace before was accepted, and later the view that the god came from Phrygia and Lydia by sea was valid (İndirkaş, 2012). Later both views were accepted (Wace, 1951). In any case, it can be argued that Dionysos is an Anatolian god.

The Hittites placed grapes at the heart of their production. Archeological findings, such as grape and wine-related cave paintings or sculptures, show the significance of the vine plant for the Hittites (Sağlam and Sağlam, 2018).
The findings from archeological excavations, such as wine potteries, grape motif coins, and grape seeds, show how deeply rooted grape cultivation and winemaking has been in the region.

The significance of grape and wine in Anatolia has always been redefined in relation to the foundational structures of civilizations, such as religion, mode of production, and governmental regimes. Nevertheless, grape cultivation and winemaking lies in the junction point of numerous Anatolian civilizations. From the ancient Greek god Dionysos to the prophet Noah, from Christianity to Islam, the vine plant and grape cultivation have always played a crucial role in determining social and cultural production.

All these have been realized with the domestication of the grape plant, Vitis vinifera ssp. Sativa and Vitis vinifera ssp. Sylvestris.

\section{Conclusion}

The determination of the domestication, distribution and origin of plant species is still an open issue. The intersection of archaeology, palaeontology, archaeobotanical disciplines and ongoing research studies are important in terms of closing the gaps and updating existing knowledge. Neverthless, the biodiversity of Anatolia and its role in the history of many 
agricultural production activities is very evident.

Even though speculation about the birthplace of Vitis vinifera ssp. Sativa and Vitis vinifera ssp. Sylvestris is an ongoing discussion, literature cited in this article reveals that Anatolia is one of the first the prime places where the grape was cultivated and wine produced. In other words, the vine plant has always been an important element for the Anatolian civilizations.

Ampelographic and molecular studies pointed out the existence of an enormous grapevine genetic resource that can be used for improving vines particularly resistant to stress factors.

In this article, along with providing information on the botanical classification and morphological structure of the grapevine plant. It was discussed how grapevine plant have been geographically distributed in Anatolia and various parts of the world. In the process, it is provided up-to-date statistics showing not only the number of vineyards and the cultivated grapes but also how grape is used in different production areas such aswine, table grapes, and raisin. Lastly, through providing climatologic statistics we have shown how suitable the vine plant is for different regions of Turkey - Anatolia and Thrace.

\section{Acknowledgments}

The authors would like to thank all editors, rewievers and Dr. Kenan Behzat Sharpe who read and contributed to the final version of the text.

\section{Conflicts of Interest}

The authors declare that there is no conflict of interest.

\section{Author Contribution}

Authors SC, IK and EB were planned the general disposition of manuscript. TU prepared the visual contents, titles of Cultivars and Uses. AA contributed to the titles of History, Uses, Culture and Arts. UA compiled the data of Statistics and Economy titles. IK and EB made critical revision of the manuscript for intellectual content. All authors read and approved the final manuscript.

\section{References}

Akgezer, B. (2018). Dionysos, Özgürlüğün Şarkısı. Yitik Ülke Yayınları.

Arroyo-García, R., \& Revilla, E. (2020). The Current Status of Wild Grapevine Populations (Vitis vinifera ssp sylvestris) in the Mediterranean Basin. Poljuha, D., Sladonja, B. (ed.) The Mediterranean Genetic Code Grapevine and Olive, IntechOpen, 1-15. https://doi.org/10.5772/52933

Arroyo-García, R., Ruiz-García, L., Bolling, L., Ocete, R., López, M. A., Arnold, C., Ergul, A., Söylemezoğlu, G., Uzun, H. I., Cabello, F., Ibáñez, J., Aradhya, M. K., Atanassov, A., Atanassov, I., Balint, S., Cenis, J. L., Costantini, L., Gorislavets, S., Grando, M. S., \& Martinez-Zapater, J. M. (2006). Multiple origins of cultivated grapevine (Vitis vinifera L. ssp. sativa) based on chloroplast DNA polymorphisms. Molecular Ecology, 15(12), 37073714. https://doi.org/10.1111/j.1365-294X.2006.03049.x

Besnard, G., Terral, J.F., \& Cornille, A. (2018). On the origins and domestication of the olive: a review and perspectives. Annals of Botany, 121, 385-403. https://doi.org/10.1093/aob/mcx145

Billiard, R. (1913). La Vigne dans I'Antiquité. Librairie H.Lardanchet.

Candar, S., Alço, T., Uysal, T., Ekiz, M., \& Yayla, F. (2019a). Determination of bioclimatic demands and maturity indicators in wine grape varieties of Karamenüş and Yayla (Vitis vinifera L.) (in Turkish with English abstract). Uluslararası Tarım ve Yaban Hayatı Bilimleri Dergisi, 5(2), 231-239. https://doi.org/10.24180/ijaws.597206

Candar, S., Alço, T., Yaşasin, A. S., Korkutal, I., \& Bahar, E. (2019b). Evaluation of long term changes for viticultural climate indices in Turkey Thrace (in Turkish with English abstract). ÇOMÜ Ziraat Fakültesi Dergisi, 7(2), 259268. https://doi.org/10.33202/comuagri.524811

Creasy, G. L., \& Creasy, L. L. (2018). Grapes. Atherton, J (ed.) $2^{\text {nd }}$ edition). Cabi.

De Mattia, F., Imazio, S., Grassi, F., Doulati Baneh, H., Scienza, A., \& Labra, M. (2008). Study of genetic relationships between wild and domesticated grapevine distributed from Middle East regions to European countries. Rendiconti Lincei, 19(3), 223-240. https://doi.org/10.1007/s12210-008-0016-6

Dietrich, O., Heun, M., Notroff, J., Schmidt, K., \& Zarnkow, M. (2012). The role of cult and feasting in the emergence of Neolithic communities. New evidence from Göbekli Tepe, south-eastern Turkey. Antiquity, 86(333), $674-$ 695. https://doi.org/10.1017/S0003598X00047840 
Ergül, A., Perez-Rivera, G., Söylemezoğlu, G., Kazan, K., \& Arroyo-Garcia, R. (2011). Genetic diversity in Anatolian wild grapes (Vitis vinifera subsp. sylvestris) estimated by SSR markers. Plant Genetic Resources: Characterisation and Utilisation, 9(3), 375-383. https://doi.org/10.1017/S1479262111000013

Eyduran, S. P., Ercisli, S., Akin, M., \& Eyduran, E. (2016). Genetic characterization of autochthonous grapevine cultivars from Eastern Turkey by simple sequence repeats (SSRs) Genetic characterization of autochthonous grapevine cultivars from Eastern Turkey by simple sequence repeats (SSRs). Biotechnology \& Biotechnological Equipment, 30(1). https://doi.org/10.1080/13102818.2015.1105726

Forni G. (2012). The origin of "old world" viticulture. In: Maghradze D, Rustioni L, Scienza A, Turok J, Failla O, editors. Caucasus and northern Black Sea region Ampelography. Vitis, special issue, 27-38.

Galet, P. (1988). Cépages et Vignobles de France, Tome 1. Les Vignes Américaines (2 ${ }^{\text {nd }}$ ed.). Imprimerie Charles Déhan.

Google. (2021). Google earth locations of some archaeological sites in Turkey. Access: 19.04 .2021

Grassi, F., \& Arroyo-Garcia, R. (2020). Editorial: Origins and domestication of the grape. Frontiers in Plant Science, 1, 1176. https://doi.org/10.3389/fpls.2020.01176

Gülcü, M. (2010). Traditional Grape Products Produced in Turkey. The $1^{\text {st }}$ International Symposium on "Traditional Foods from Adriatic to Caucasus". 15-17 April, Tekirdağ, Turkey.

Hizarci, Y., Ercisli, S., Yuksel, C., \& Ergul, A. (2012). Genetic characterization and relatedness among autochthonous grapevine cultivars from Northeast Turkey by Simple Sequence Repeats (SSR). Journal of Applied Botany and Food Quality, 85(2), 224-228.

İndirkaş, Z. (2012). Dionysos tanrinin maskesi ya da maskenin tanrısı (in Turkish with English abstract). Journal of Theatre Criticism and Dramaturgy 15. Retrieved from https://dergipark.org.tr/tr/pub/teddergi/issue/18489/194635

Jackson, R. (2014). Wine Science-Principles and Applications (4 ${ }^{\text {th }}$ Edition). Academic Press. 978 p. eBook ISBN: 9780123814692

Johnson, H. (1989). The Story of Wine. Mitchell Beazley.

Karataş, D.D., Karataş, H., Laucou, V., Sarikamiş, G., Riahi, L., Bacilieri, R., \& This, P. (2014). Genetic diversity of wild and cultivated grapevine accessions from southeast Turkey. Hereditas, 151(4-5), 73-80. https://doi.org/10.1111/hrd2.00039

Keller, M. (2015). The Science of Grapevines: Anatomy and Physiology: $2^{\text {nd }}$ Edition. https://doi.org/10.1016/C2013$\underline{0-06797-7}$

Korkutal, İ., Bahar, E., Kök, D., Şahin, N., Uysal, T., Özalp, Z. O., Yaşasın, A. S., Candar, S., Alço, T., \& Işın, M. A. (2018). Collecting genetic materials and isolating DNAs of grapevine (Vitis spp.) as naturally grown in Ganos Mountains (in Turkish with English abstract). Mediterranean Agricultural Science 37(1), 5-15. https://doi.org/10.29136/mediterranean.377609

Kök, D., Bahar, E., Korkutal, I., Bal, E., Alço, T., Candar, S., \& Yaşasin, A. S. (2018). Determination of phytochemical properties in genetic materials collected from grapevines (Vitis spp.) found in natural flora of Ganos mountains. Journal of Tekirdag Agricultural Faculty, 15(3), 52-60.

Köse, B. (2014). Varieties in the maritime climate of Samsun in Turkey's Black Sea region. South African Journal of Enology and Viticulture, 35(1), 90-102.

Laflı, E. (2017). Antik Hellen ve Roma Dönemlerinde Anadolu'da Bağcılık ve Şarapçılık. Dinç Ofset Matbaa.

Levadoux, L. (1956). Les populations sauvages et cultivés de Vitis vinifera L. Annales de l'Amélioration Des Plantes, $1,59-118$.

Maghradze, D., Melyan, G., Salimov, V., Chipashvili, R., Íñiguez, M., Puras, P., Melendez, E., Vaca, R., Ocete, C., Rivera, D., Obón, C., Valle, J. M., Rodriguez-Miranda, A., Failla, \& Ocete, R. (2020). Wild grapevine (Vitis sylvestris C.C.Gmel.) wines from the Southern Caucasus region. Oeno One, 54(4), 849-862. https://doi.org/10.20870/OENO-ONE.2020.54.4.3720

Marvelli, S., De'Siena, S., Rizzoli, E., \& Marchesini, M. (2013). The origin of grapevine cultivation in Italy: The archaeobotanical evidence. Annali Di Botanica, 3, 155-163. https://doi.org/10.4462/annbotrm-10326

McGovern, P. E. (2003). Ancient Wine: The Search for the Origins of Viniculture. Princeton University Press, Princeton. ISBN: 9780691197203

McGovern, P., Jalabadze, M., Batiuk, S., Callahan, M. P., Smith, K. E., Hall, G. R., Kvavadze, E., Maghradze, D., Rusishvili, N., Bouby, L., Failla, O., Cola, G., Mariani, L., Boaretto, E., Bacilieri, R., This, P., Wales, N., \& Lordkipanidze, D. (2017). Early Neolithic wine of Georgia in the South Caucasus. Proceedings of the National Academy of Sciences of the United States of America, 114(48), E10309-E10318. https://doi.org/10.1073/pnas.1714728114

Mullins, M. G., Bouquet, A., \& Williams, L. (1992). Biology of the Grapevine. Cambridge University Press. Negrul, A.M. (1960). Arkheologicheskie nakhodi semian vinograd. Sovetskaya Arkheologiya, 1, 111-119. 
Nicotra, A.B., Leigh, A., Boyce, C.K., Jones, C.S., Niklas, K.J., Royer, D.L., \& Tsukaya, H. (2011). The evolution and functional significance of leaf shape in the angiosperms. Functional Plant Biology 38(7), 535-552. https://doi.org/10.1071/FP11057

OIV. (2020). State of the World Vitivinicultural Sector in 2019. Retrieved from http://www.oiv.int/public/medias/7298/oiv-state-of-the-vitivinicultural-sector-in-2019.pdf. $\quad$ Access: 29.03.2021.

Özkaya, V., \& San, O. (2007). Körtik Tepe: Bulgular Işı̆̆ında Kültürel Doku Üzerine Ilk Gözlemler. Başgelen, N (Ed.), Anadolu'da Uygarlığın Doğuşu ve Avrupa'ya Yayılımı: Türkiye'de Neolitik Dönem, Yeni Kazılar, Yeni Bulgular. p. 217. Arkeoloji ve Sanat Yayınları. Mas Matbaacılık.

Öztürk, M. Z., Çetinkaya, G., \& Aydın, S. (2017). Climate types of Turkey according to Köppen-Geiger Climate Classification (in Turkish with English abstract). Cografya Dergisi, 35, 17-27. https://doi.org/10.26650/jgeog295515

Papp, B., \& Sabovljević, M. (2003). Contribution to the Bryophyte flora of Turkish Thrace. Studia Bot. Hung, 34, 4354.

Piperno, D. R., Weiss, E., Holst, I., \& Nadel, D. (2004). Processing of wild cereal grains in the Upper Palaeolithic revealed by starch grain analysis. Nature, 430(7000), 670-673. https://doi.org/10.1038/nature02734

Ramishvili, R. (1983). New archaeological evidence on the history of viniculture in Georgia. Matsne 2, $127-40$.

Riaz, S., De Lorenzis, G., Velasco, D., Koehmstedt, A., Maghradze, D., Bobokashvili, Z., Musayev, M., Zdunic, G., Laucou, V., Andrew Walker, M., Failla, O., Preece, J. E., Aradhya, M., \& Arroyo-Garcia, R. (2018). Genetic diversity analysis of cultivated and wild grapevine (Vitis vinifera L.) accessions around the Mediterranean basin and Central Asia. Plant Biology, 18(1), 137. https://doi.org/10.1186/s12870-018-1351-0

Sağlam, Ö. Ç., \& Sağlam H. (2018). İnsanlık tarihinde üzümün önemi. Journal of Agriculture, 1(2), 1-10.

Savard, M., Nesbitt, M., \& Jones, M. K. (2006). The role of wild grasses in subsistence and sedentism: New evidence from the northern Fertile Crescent. World Archaeology, 38(2), 179-196. https://doi.org/10.1080/00438240600689016

Schmidt, K. (2010). Göbekli Tepe - The Stone Age sanctuaries. New results of ongoing excavations with a special focus on sculptures and high reliefs. Documenta Praehistorica, 37(1), 239-256. https://doi.org/10.4312/dp.37.21

Smith, A. (2008). Wine in Anatolia. Selin, H., (Ed.), Encyclopaedia of the History of Science, Technology, and Medicine in Non-Western Cultures, pp. 2281-2283. Springer Netherlands. https://doi.org/10.1007/978-1$\underline{4020-4425-0.8942}$

Şenocak, E. (2008). The place of grape in Turkish folk culture and in context of mythology. Journal of Turkish Studies, 3(3), 175-192. https://doi.org/10.7827/turkishstudies.418

This, P., Lacombe, T., \& Thomas, M. R. (2006). Historical origins and genetic diversity of wine grapes. Trends in Genetics, 22(9), 511-519. https://doi.org/10.1016/j.tig.2006.07.008

TUIK. (2021). Grape production areas and quantities in 2020 according to usage purpose. Turkish Statistical Institue Data Portal for Statistics. https://biruni.tuik.gov.tr/medas/?kn=92\&locale =tr

Turkes, M. (2019). Climate and Drought in Turkey. Harmancıoğlu, N.B., Doğan, A. (Eds.), Water Resources of Turkey (pp. 85-125). Springer, Cham. https://doi.org/10.1007/978-3-030-11729-0 4

Uhri, A. (2017). Üzümün Doğu Akdeniz'deki Uzun Yolculuğu. In "Üzümün Akdeniz'deki Yolculuğu Konferans Bildirileri". Dinç Ofset Matbaa.

Unwin, T. (1991). Wine and the Vine: An Historical Geography of Viticulture and the Wine Trade (1 $1^{\text {st }}$ Ed.). Routledge. https://doi.org/10.4324/9780203013267

Uysal Seçkin, G., \& Taşeri, L. (2015). Semi-dried fruits and vegetables. Pamukkale University Journal of Engineering Sciences, 21(9), 414-420. https://doi.org/10.5505/pajes.2015.47560

Uysal, T., \& Candar, S. (2017). The Importance of Vine Genetic Resources in Traditional Grape Products. International Symposium on Biodiversity and Edible Wild Species, 207.

Uysal, T., Yaşasın, A. S., Onur, E., \& Özalp, Z. O. (2020). The Researches on Determination, Preservation and Description of Vine Genetic Sources Of Turkey (in Turkish with English abstract, interim report 2015-2019). https://arastirma.tarimorman.gov.tr/bagcilik/Menu/7/Sonuclanan-Projeler

Vivier, M. A., \& Pretorius, I. S. (2002). Genetically tailored grapevines for the wine industry. Trends in Biotechnology, 20(11), 472-478. https://doi.org/10.1016/S0167-7799(02)02058-9

Vouillamoz, J. F., McGovern, P. E., Ergul, A., Söylemezoğlu, G., Tevzadze, G., Meredith, C. P., \& Grando, M. S. (2006). Genetic characterization and relationships of traditional grape cultivars from Transcaucasia and Anatolia. Plant Genetic Resources, 4(2), 144-158. https://doi.org/10.1079/pgr2006114

Wace, A. J. B. (1951). The Minoan-Mycenaean Religion and its Survival in Greek Religion. By Nilsson, M.P. (Acta Reg. Soc. Hum. Litt. Lundensis, IX.) Pp. xxiv + 656. (Second, revised edition.) Lund: Gleerup, 1950. Kr. 50. The Antiquaries Journal, 31(3-4), 211-212. https://doi.org/10.1017/s0003581500076526 
Wang, C., He, J., Zhao, T. H., Cao, Y., Wang, G., Sun, B., Yan, X., Guo, W., \& Li, M. H. (2019). The smaller the leaf is, the faster the leaf water loses in a temperate forest. Frontiers in Plant Science, 10. https://doi.org/10.3389/fpls.2019.00058

Yılmaz, F., Shidfar, M., Hazrati, N., Kazan, K., Yüksel Özmen, C., Uysal, T., Özer, C., Yaşasın, A. S., Söylemezoğlu, G., Boz, Y., Çelik, H., \& Ergül, A. (2020). Genetic analysis of central Anatolian grapevine (Vitis vinifera L.) germplasm by simple sequence repeats. Tree Genetics and Genomes, 16(4). https://doi.org/10.1007/s11295-020-01429-z

Zeder, M. A. (2011). The Origins of Agriculture in the Near East. Current Anthropology, 52, 221. https://doi.org/10.1086/659307

Zohary, D., \& Hopf, M. (2000). Domestication of Plants in the Old World: The Origin and Spread of Cultivated Plants in West Asia, Europe, and the Nile Valley ( ${ }^{\text {rd }}$ ed.). Oxford University Press. 